\title{
Thinking with Reproduction: Maternal Time, Citizenship, Migration and Political Subjectivity
}

DOI:

10.1057/sub.2015.22

Document Version

Accepted author manuscript

Link to publication record in Manchester Research Explorer

\section{Citation for published version (APA):}

Ní Mhurchú, A. (2016). Thinking with Reproduction: Maternal Time, Citizenship, Migration and Political Subjectivity. Subjectivity, 9(1), 17-37. https://doi.org/10.1057/sub.2015.22

\section{Published in:}

Subjectivity

\section{Citing this paper}

Please note that where the full-text provided on Manchester Research Explorer is the Author Accepted Manuscript or Proof version this may differ from the final Published version. If citing, it is advised that you check and use the publisher's definitive version.

\section{General rights}

Copyright and moral rights for the publications made accessible in the Research Explorer are retained by the authors and/or other copyright owners and it is a condition of accessing publications that users recognise and abide by the legal requirements associated with these rights.

\section{Takedown policy}

If you believe that this document breaches copyright please refer to the University of Manchester's Takedown Procedures [http://man.ac.uk/04Y6Bo] or contact uml.scholarlycommunications@manchester.ac.uk providing relevant details, so we can investigate your claim.

\section{OPEN ACCESS}




\title{
Thinking with Reproduction: Maternal Time, Citizenship, Migration and Political Subjectivity
}

Aoileann Ní Mhurchú ${ }^{1}$, School of Social Sciences, University of Manchester Published in Subjectivity Vol.9 2016, Issue 1: pp17-37

\begin{abstract}
This article thinks with reproduction (what Baraitser and Tyler call "natal thinking" $(2013$, p.3)) to conceptualise its role as both an empirical and theoretically rich site through which to further develop thinking about citizenship as fluid (in flux). Focusing on the mother-child (born and unborn) subject, the article considers the manner in which thinking with the cyclical and eternal time of reproduction reconfigures the possibility of political community and political identity through the idea of repetition which undoes at the same time as it repeats. The paper reflects upon how actions by migrant mothers undo (exceed) at the same time as they repeat understandings about the role of inclusion (commonality) versus exclusion (otherness) in citizenship. It argues that such acts can be seen as that which invoke excess and otherness in political subjectivity as another starting point for/of political possibility rather than just as an exception.
\end{abstract}

Key Words: citizenship; maternal time; migration; political subjectivity; reproduction

\footnotetext{
${ }^{1}$ aoileann.nimhurchu@manchester.ac.uk
} 


\section{Introduction}

Baraitser and Tyler note (2013) that the act of birthing has been propelled into visual culture in recent decades, undermining taboos around the birth scene and the body of the mother experiencing pain and pleasure. This behooves, they argue, not only more thorough social and political accounts of the place of birth and reproduction in contemporary culture, but also more forms of thinking with reproduction (what they call "natal thinking" (ibid, p.3) to conceptualise its role in the construction of politics and the social as we move away from the idea of birth as "just "natural' - as something that simply happened before man "is"" - as has been dominant in European continental philosophic imaginary (Battersby 1998, p.18). With this in mind, this paper focuses on the manner in which thinking with the cyclical and eternal time of reproduction (maternal time) reconfigures the possibility of political community and political identity through the idea of repetition which undoes at the same time as it repeats. It does so by focusing on the mother-child (born and unborn) subject as a differentially positioned subject and looking at the actions and lives of migrant mothers it considers how these undo (exceed) at the same time as they repeat understandings about the role of inclusion (commonality) versus exclusion (otherness) in citizenship. Its contribution is that it helps us to understand public acts by migrant mothers as that which invoke excess and otherness in political subjectivity as another starting point for/of political possibility rather than just as an exception to political possibility.

For, there has been increased attention in recent decades on the need to approach political subjectivity from a critical perspective which is attentive to how citizenship works through flux; that is, how it works beyond unity and instead in terms increasingly of interruptions, multiplicities, fragmentation and confrontations (Isin 2009), resulting in differential political inclusions (Andrijasevic 2009). This approach complicates the timespace of the nation-state by asking questions about in-between or multiple times and spaces of encounter and co-presence (Closs Stephens 2010). Doing so, it tells a story about citizenship as something which is produced through its outsiders, aliens and Others, rather than against them. This emphasis on the (constant) reproduction of citizenship has been used to think about the politics of reproduction and mothering as an act of citizenship, in particular in the context of immigration (Erel 2013). What is pointed to is the need to think about how migrant women not only act as reproducers of future generations of national and non-national offspring but also the way in which their actions interrupt the boundaries of the state (and associated cultural unity) in keeping with ideas of growing diversity (c.f. Vertovec 2007). 
With this in mind, this paper explores how we can understand reproduction as both an empirical and theoretically rich site through which to further develop thinking about citizenship as fluid (beyond unity). It does so by focusing in particular on the mother-child (born and unborn) subject as differentially positioned subjects of migration.

The paper begins by drawing out some of the difficulties of theorizing the simultaneous experience of citizenship as commonality and otherness given the continued adherence (in subtle ways) to an autonomous bounded individual subject within some existing debates about citizenship and reproduction. It argues that these discussions reaffirm demarcated space (rather than fragmented or multiple spaces) through their emphasis on the idea of citizenship as full membership status and through their appeal to the idea of political community as that which people can be fully included into as individuals. The paper emphasises the idea of an intertwined mother-child subject as an alternative image to the autonomous individual subject which has been subtly maintained here; it argues that the intertwined subject (explored in the idea of mothers travelling across borders with a child in utero and their various interrelationships with others across society) is very useful for thinking about a transitive form of being in the world (across commonality and otherness) which is not exceptional but rather is part of the possibility for political subjectivity and belonging. The paper works with Julia Kristeva's idea of maternal time to theorise the kinds of coeval political subjectivities that are at stake with migrant mothers and their children. The theoretical analysis in the paper is grounded in discussion of the so-called "citizenship tourists" debate in the Republic of Ireland.

\section{Political Subjectivity and the Persistent Focus on Inclusion}

Despite recent discussions about the need to uncover alternative spatialities and temporalities of citizenship, "which either defy or at least complicate the space-time of the nation-state" (Closs Stephens and Squire 2012, p.434) citizenship remains linked in some respects to a dominant story, as noted by Engin Isin (2002). This is a story about a group of people whose identity as citizens is articulated at the same time as another group is defined as lacking the properties deemed necessary for citizenship and are constituted to varying degrees as strangers, aliens and Others. It is told about people moving from spaces of exclusion and nonbelonging (or partial-belonging) into spaces of inclusion and belonging. Doing so, it reaffirms understandings of the linear time and absolute space of the nation-state: citizenship is 
understood "to be achieved in time, extended in space...passed to, handed out, or taken away from communities..." (Closs Stephens 2010, p.32).

Linda Bosniak suggests that one of the key problems with many approaches to citizenship is an ongoing attachment to a particular ideal of citizenship "as the highest fulfillment of democratic and egalitarian aspiration" which obscures "the deeper challenges that the concept poses" (Bosniak 2006: 1). The challenge I want to focus on is how citizenship is simultaneously linked not just to inclusion and identity - through concepts such as "democratic citizenship" and "equal citizenship" - but also to experiences of exclusion and otherness given its association with borders and the non-citizen other which it stands in contrast to. Doing so I am drawing upon insights from both Critical Citizenship Studies (CCS) and ideas of cultural citizenship. The former has developed the idea of citizenship as a performative concept which is done, enacted, and put into play in various contextualised social, cultural and economic milieus (Isin and Neilson 2008). The latter has considered citizenship "beyond the dichotomous categories of legal documents, which one either has or does not have, to encompass a range of gradations in the qualities of citizenship" (Rosaldo 1994, p.57). Here the idea of citizenship is understood as a concept in process across cultural, legal, social and, economic realms. Such literature explores the disjunctive (contradictory) nature of citizenship in its manifestation as well as refusing the distinction itself between "an ideal" and a "lived experience" of citizenship (Clarke et al 2014; Ong 1999). They explore how we can conceive of politics and political subjectivity beyond both a legal status and a rights bearing subject (McNevin 2011; Ní Mhurchú 2014a).

This type of literature can be contrasted with literature which instead focuses on how certain people are excluded from citizenship - including women, those with precarious status, migrants and ethnic minorities. The former literature focuses on citizenship as disjunctive in its manifestation; it sees exclusionary aspects of citizenship as part of citizenship rather than undermining it. In contrast, the latter continues to focus on citizenship as a status of full inclusive rights which certain people can claim as "citizens" and from which others are excluded rendering them incomplete citizens ("partial citizens" (Bauböck 2011)). In her work, Ruth Lister demonstrates how the tension between citizenship's inclusionary and exclusionary sides is not ignored here. Rather the decision has been made to specifically focus on the struggle for social inclusion through "the standpoint of the excluded" (Kabeer quoted in Lister 2007, p.50). What is important to note is that unlike the former approach it presumes that we can separate the exclusionary and inclusionary aspects of citizenship. The idea that citizens and non-citizens occupy multiple positions of inclusion and exclusion is not 
ignored here. For example, such authors often expressly set out to look at differences between women on the basis of gender, race and class and point to the different ways in which women, including migrant women, take part in or initiate political activism which undermine simple ideas of political 'inclusion' or 'exclusion'. However, despite noting how 'citizenship' is constituted through (racialized, class and gendered etc.) exclusions and the ways these are challenged, the emphasis remains on how this exclusion defines (is productive of) the limitations, problems, lack in membership (c.f. Bhabha 2009; Sawyer and Blitz 2011): exclusion is thus explored as that which undermines membership at the same time as it constitutes it.

The emphasis within this latter (inclusivist) perspective thus continues to be on the inclusionary basis of citizenship despite associated exclusions. The exclusionary aspects are traced back to the way in which the boundaries of citizenship were constructed through particular understandings of race, gender, ethnicity, class and so on at an initial founding moment. Exclusionary aspects of citizenship are thus understood as separable from inclusionary aspects of citizenship, despite making up citizenship; this can be constrasted with explorations of how inclusionary and exclusionary aspects are intertwined together as 'citizenship', with them constantly shifting and changing and escaping normative evaluation, as put forward under CCS and literature on cultural citizenship.

For example, it continues to be stated in the inclusivist perspective that citizenship "governs the relationship between the individual and the collectivity - does one belong or is one an 'outsider'?" (Bhabha 2009, p.218; Mullally 2005; Sarat 2013). This is to define the politics of citizenship in terms of the rights (to be included in political community) which people hold as individuals vis-à-vis the state. In her work, Jacqueline Bhabha (2009, p.218), for example, considers who is left out of full citizenship ("excluded or marginalised from membership") and focuses on the need to bring them back from the edges of membership by ensuring "access to an effective voice in local or national government". When considering the lives of children born to migrants Bhabha, links the "real meaning" of citizenship to "permanence of access" to the attributes of social and private life in the home country including full rights to family life, social support and civil and political freedoms (ibid, original emphasis). She argues that "it is the permanence of access to these social goods, the fact of non-deportability for the present and the future, that distinguishes the rights of the citizen child from those of the noncitizen child, not the access itself." The point is that citizenship is linked here specifically to a (recognised problematic, but nonetheless) supposedly necessary dualistic inclusion/exclusion basis. It is underwritten by a continued 
normative imperative that citizenship should be experienced in a progressive inclusive manner "which is...pluralist, reflexive and participatory" (Lister 2007, p.4). Even though such work does not ignore the lived experiences and constitutive nature of how citizenship has been produced as less than this, the division between less-than (exclusionary) and greaterthan (inclusionary) aspects is maintained. In doing so, citizenship, as I discuss in more detail in the next section, remains linked to bounded space: both at the level of subjectivity through appeals to the importance of individual rights, and at the level of community through appeals to the idea of an inclusive political community.

What this does not permit us to explore is how citizenship is often revoked and invoked in inconsistent and fragmented ways which undermine how we have come to understand 'inclusionary' and 'exclusionary' aspects of citizenship. It is less helpful for considering how the citizen-subject is infused with foreignness, strangerhood and otherness across inclusion and exclusion in ways which cannot be separated out. This is not simply to challenge outright the distinction between citizenship as an ideal and lived everyday experiences of citizenship, which authors writing within the inclusivist approach have been instrumental in doing. It also involves questioning the understanding of an inclusionary ideal within everyday experience as a core aspect of 'citizenship'.

The reason this is important, is because for example, it is increasingly noted that experiences of tension are part of the lives of first generation migrants, as well as intergenerational migrants who inhabit an "elusive borderzone" between inclusion and exclusion, between inside and outside (Mezzadra 2011, p.130). Referred to variously as "illegal citizens", "irregular citizens" or "ambiguous citizens", what is looked at is how some people engage in inconsistent ways and at inconsistent times in the state in which they reside: for example, spending long periods employed under visas which are later revoked; paying taxes through self-employment despite not being permitted to undertake paid employment; or, being entitled to normal social welfare and educational rights without full family reunification rights (McNevin 2011; Ní Mhurchú 2014b; Nyers 2011; Rigo 2011).

Such experiences draw attention not only to the ways in which traditional territorial understandings of citizenship are being challenged by processes such as migration, thereby blurring the boundary between citizens and non-citizens. They also point to the ongoing inconsistent ways in which people engage in being (becoming) political subjects. These are experiences which are in the process of drawing out contradictions within citizenship and thus reconfiguring the nature itself of citizenship, as Étienne Balibar (2000) has discussed in the context of the Sans Papiers in France and Cynthia Weber (2011) has explored in the 
context of various groups in the US including indigenous peoples, and migrant mothers. Such studies demonstrate the ways in which the everyday political experiences of many people fall short of the dominant understandings of marginality and exclusion or commonality and inclusion. They suggest meaning, I argue, that exceeds the rules through which we have come to understand political community. No longer experiences which can be understood as dualistic spaces, they are not experiences on a continuum of dualistic space(s) which produce partial forms of citizenship such as "denizen" either. Rather, they are experiences which point increasingly to tensions ("antinomies" (Balibar 2012)) within citizenship. These are tensions between rights and duties, membership and exclusion, participation and representation etc. which citizenship is made up of, rather than exceptions to a clearly demarcated citizenship realm (Bosniak 2006; Turner forthcoming 2016). They are experiences of citizenship beyond commonality because they are overlapping, inconsistent (often contradictory) simultaneous experiences of unity and otherness, belonging and not-belonging, past and present, inclusion and exclusion.

Taking this approach raises questions about the nature of political community itself. It involves not just considering how political community is challenged by or co-exists with other types of community - such as ethnic, cultural, or social community - and thus how "community" can involve new forms of inclusion and exclusion outside of politics. Rather it involves asking questions about how politics itself is being reconfigured through citizenship beyond "an expression of claims about temporality and history enabling constitutive discrimination between those who belong... and those who do not" (Walker 2010, p. 99).

In relation to debates about reproduction, one key way of attempting to think outside of bounded space in respect of citizenship is through a civic understanding of citizenship (naturalisation) and citizenship based on birth. What is argued is that these are more fluid options in contrast to citizenship by descent (jus sanguine) because they promote an understanding of society which is grounded in shared values (naturalisation) or in the accident of birth rather than in fixed ethnic ties (c.f. Honohan 2007; Howard 2009). As eloquently outlined by Ayelet Shachar (2009), this ignores however the way in which the former prioritises place of residence and the latter prioritises place of birth (over descent and parentage), thus clearly defining and fixing the subject once again. That said, birthright offers the potential I argue to help us rethink our understanding of the citizen-subject as necessarily tied to exclusive bounded space in a different way. In order to do so I first turn more closely to look at how citizenship has been defined in terms of inclusion and the unitary subject through debates about so-called "citizenship tourists" in Ireland. I then go on to consider the 
lives of and actions by migrant women within this context. Pregnancy has traditionally been a battleground about understandings of the nation in Ireland (Oaks 1998); and a referendum in 2004 over citizenship made it a site of debate about the meaning of political community once again, this time in both a national and a European sense. What this empirical example draws attention to I argue is how the pregnant body subverts attempts to fit it within even broadly fluid inclusionary ideas of citizenship and belonging. I explore how it does so below through two examples; firstly through migrant mother activist engagement in Ireland which is produced through exclusion and otherness in a way that is inseparable from inclusionary aspects; and secondly, through claims to "living" by migrant mothers as the basis of citizenship and the messiness this entails which exceed inclusionary status. Both of these point to how reproduction undermines, as I go on to argue, the inclusionary ideals of citizenship located in linear progressive time.

\section{The "Citizenship Tourist" Debate}

In recent decades public debates about birthright citizenship have revolved around the persuasiveness of the idea that certain people's citizenship status should be viewed suspiciously: as "a kind of unjust enrichment, opportunistically acquired" (Ngai 2007, p.2025). In 2004 the notion of "citizenship tourists" was used by the Irish Government to question the right of Irish-born children of migrant parents (and therefore people who were Irish citizens as well as EU citizens by birth) to reside freely in Ireland and to move freely within the European Union with their parents (Hanafin 2004). As a result of the fears raised by the Irish Government regarding "citizenship tourists", an overwhelming majority of the Irish population (79.2\%) voted in a referendum in 2004 to remove the then automatic constitutional entitlement to birthright citizenship.

Such attempts to amend citizenship legislation have been criticised by citizenship scholars for codifying a system which is based on speculation and anecdotal evidence and which discriminates against immigrant women by making it more difficult for their children to be recognised as Irish at birth under new rules (Garner 2007). The emphasis in this literature is rightly on the need to rethink how we understand the boundaries of political community to be fixed at a given moment in time - for example, at the founding moment of the state. However I argue that political subjectivity continues to be conceptualised in such literature vis-a-vis the state in terms of bounded (sovereign and autonomous) selves in the last instance given the emphasis on the possibility of full inclusion in and exclusion from political community. 
This inclusivist scholarship allows us to both explore how women's sexuality and childbearing works through processes of exclusion while it also creates room to rework and renegotiate these processes in more inclusive ways. Such scholarship most notably invokes a rich history of the role of migrant women in actively (re)producing the nation beyond initial founding moments: both literally (by giving birth to the next generation) as well as figuratively (by embodying alternative national cultural traits) (Yuval Davis and Anthias 1989). For example, it argues that migrant women come to embody the potential for alternative boundaries of "Irish" political community through their role as reproducers of future generations of traditionally "non-Irish" offspring (Lentin 2004; Luibhéid 2004). However, the point is that the idea of the political subject as a marginalised subject who can become coherently included in a bounded political community in the present persists here. It persists through the idea that they do so by moving away from exclusion and otherness (migrancy) in the past towards belonging (citizenship) in the present and future - even if only as an ideal form of citizenship.

Much of this literature emphasises the intersectionality of various axis of subordination - such as gender, race, sexuality, ethnicity, as well as class, and country of origin (e.g. Mullally 2009). However, the underlying idea of a unitary political subject (sovereign individual) who sits at the centre of this axis of subordination as the "migrant woman" and "the Irish-born child" who are differentiated from the "citizen woman" and "the Irish child" persists in this particular intersectionality approach. ${ }^{i}$ As such political identity defined in terms of the citizen/migrant, included/excluded dualistic axis remains in place. The interpretive scope of this approach does not therefore interrupt the dominant dualistic logic of citizenship and the political despite pointing to the need to do this; it does not prioritise differential inclusion: "the stratification and proliferation" of politics and citizenship which undermines the ability to separate out inclusionary and exclusionary aspects of citizenship (Andrijasevic 2009, p.392; Mezzadra and Neilson 2012). The next section looks at how we can rethink the citizen beyond the unitary and sovereign subject (who can be included or excluded) using the illustrative example of debates about the Irish-born child as "the suspect ‘alien citizen"” (Ngai 2007).

\section{Citizen-Subjectivity: Overlapping and Intertwining}

Rather than thinking about birthright citizenship by focusing on the rights which migrant women and their children hold as individuals - as has been done a lot in existing literature, I 
focus here on this issue through the notion of "rites of passage" (Shandy 2008, p.813) in order to take a more "relational" perspective as has been called for (Closs Stephens and Squire 2012). This turns our attention towards the processes through which the identities of mother and child are produced, and away from focusing on a pre-existing rights-bearing subject position such as "the individual" which re-grounds citizenship within another clearly defined space. This is not to ignore the importance of recognising how people are positioned vis-à-vis the state as individuals, but to rethink the existing exclusive focus on the "triangular relationship" (Shandy 2008, p.813) between the bounded entities of child, mother and state.

\section{From Individual Rights to Rites of Passage}

Central to discussions about citizenship tourists in 2004 were African women, a large majority from Nigeria. It was these women who were "stereotyped as sexually active childmakers, deliberately subverting Irish norms of citizenship and nationality" (Lentin 2004, p.305). Oyeronke Oyewumi (2010, p.7) observes that "at the moment of birth, two entities are born - a baby and a mother", noting for example, how in Yoruba culture - which spans the modern states of Nigeria, Benin and Togo - "children are the ultimate work of art...and mothers its privileged creation." She emphasises in other words the idea that birth ushers in new relations of subjectivity for both the woman and the child. These are relations which extend beyond the idea of the individual and legal or social personhood tied to the state, and which instead tie the child and mother to each other and to their community at large (via family). This makes it very difficult to point to where either the mother or the child subject ends and their inclusion in Africa, Nigeria or Ireland begins, as these subjectivities are integral to the conceptualisation of these political communities.

For example, Shandy $(2008$, p.814) points out that birth in African societies has a symbolic importance within the family and thus the wider community, both producing new child and mother subjectivities and implicating other family members in these subjectivities and in their (inter)relationship.

In brief, a woman who becomes a mother is likely to experience an increase in power vis-àvis her husband, and by extension, within her husband's family. This augmentation of power, will in turn shift relations within her own family. And this has a knock-on, or domino, effect in shifting power relations between her family and her husband's family.

This is not a unique situation. In Irish society, women as mothers have a special role in the Irish Constitution which indicates (albeit in a more formal sense) how reproduction in Irish society also facilitates a new "mother" subject. Article 41 of the Irish Constitution (2012) recognises the family "as the natural primary and fundamental unit group of Society". It 
states that "[T]he State shall...endeavour to ensure that mothers shall not be obliged by economic necessity to engage in labour to the neglect of their duties in the home." In doing so it enshrines the role of the mother subject and equally importantly co-implicates (as above) family members - which include fathers, husbands, partners, siblings, grandparents - in the relationship between mother and child.

Such continuities are important to note to interrupt the neo-colonial binary between Africa and Ireland which was set up during this "birth tourism" debate. Indeed "Africa" and "Ireland" as the categories structuring this debate are very uneven; for there is no specific socio-historical-legal citizenship grounded in Africa unlike the socio-historical-legal Irish citizenship to which it is juxtapositioned. However Africa is also a category from which many people in Ireland draw strength and challenge their designation as non-citizens. This is reflected in Irish-based migrant organisations such as AkiDwA (short for Akina dada wa Africa which means "sisters of Africa"). This paper therefore does not reject, but attempts to think about how the category of Africa can be recited and replayed in ways which are unfamiliar and which draw out the spatio-temporal complexity (Mezzadra and Rahola 2006) of the challenge posed by many lives in Ireland to such neo-colonial imagery.

Looking at continuities across African and Irish society allows us to consider that when the process of birth feeds into the act of migration, the distinction between the mother and child subjects and their "community" (Ireland, Africa, Nigeria, Yoruba etc.) is always already very complex across gendered, ethnic, aesthetic, and class understandings. It is not only a question of how the mother and child as subjects interact "in" the political community which they can be separated from. Rather, the child is often an integral part of how a woman is recognised as a political subject (a mother) who is a member of that community; and the mother is often an integral part of how that child is seen as a member of the political community (for example, linked to whether the mother is married and/or who she is married to) (Seely et al 2013). It similarly connects wider society together through women and children, thus foregrounding interconnections (fluidity) as the basis for the possibility of political community. Yet, as Shandy notes (2008, p.818) "much of the rights-based discourse on these African women and their children ignores these broader transnational linkages that connect these immigrants to larger social groupings."

The reasons why women from across Africa end up in Ireland are multifarious, including the desire to study, to work, to join a spouse or other family members who are already working in Ireland, as well as to access asylum or maternity services. These reasons 
furthermore shift and change over time and are not discrete or fixed but often evolving and overlapping. Many women come to accompany their husbands, to take a job, or to study and only subsequently apply for a visa on the basis of giving birth to a child in Ireland (ibid, p.812). This presents an infinitely complex picture of the migrant woman subject with conflicting roles and tied in potential ways through her child to various others (such as partners, fathers, and wider family members) and thus tied in ongoing ways to Ireland as well as to Africa and to particular states within Africa such as Nigeria or trans-statist regions such as Yoruba. These are not captured in the image of a sovereign individual subject nor in ideas of fluidity as (merely) exceptional given the ways in which these experiences implicate many other subjects in society in ongoing every-day mundane ways. Below I explore the less-than individual (non-unitary) subjectivity of the mother subject in more detail.

\section{Fragmented and overlapping Citizen-Subjectivity}

There has been a tendency in citizenship literature to argue that the boundaries of exclusion/inclusion, not-belonging/belonging are brought into sharp focus and exacerbated in an age of globalisation (c.f Dauvergne 2009). Developing this idea Angela Smith argues that "[i]t is the mother's status that...creates a second class of Irish-born but not Irish citizen children. She and her children do not belong" (Smith 2008, p.76). What this downplays, however, is how such subjects do participate in society albeit often in an unconventional sense to how "political participation" is traditionally linked to formal institutional participation.

Indeed, what is pointed to in existing research is the increasingly complex ways in which migrant women act politically through their maternal identities and beyond through a range of roles, which include without being limited to, as students; volunteers; part-time, domestic or self-employed workers; activists; friends; girlfriends; neighbours; and/or wives (Erel 2009, 2013; Reynolds 2005). The way in which migrant women participate as political members through struggles to extend their rights and those of others is increasingly documented as that furthermore which challenges how we have come to know politics and its supposed links to inclusion and unity by drawing out its links to exclusion and otherness as well (Raissiguier 2010). For example, engagement by migrant women often stems from selfprofessed "migrant issues", but these can draw upon and reinforce wider traditional concerns regarding wellbeing, quality of life, democracy, and safety which the political communities in which they live - e.g. "Ireland" or "France" or "Britain" - ascribe to. In the Irish case, a key example can be seen in the work of AkiDwA, a national network of migrant women living in 
Ireland which addresses gender-based violence, in particular Female Genital Mutilation (FGM). FGM is seen as a healthcare issue which is linked to "new" communities (i.e. based on otherness) within Irish society (AkiDwa 2013, p.6). Nonetheless, while the focus of this group's activities is driven through concerns at the level of self-professed migrant families and their local communities (as those who are different within Irish society), it has resulted in a bill being passed in the Irish parliament (the Criminal Justice [Female Genital Mutilation] Act 2012). Furthermore, a 'National Plan of Action to Address FGM' was developed as part of Ireland's commitment to an EU endorsed Human Rights agenda (ibid).

What can be seen here is how political participation draws upon, and works through processes of otherness, tension and exclusion as well as through processes of inclusion, commonality and resolution. Yet, this emphasis on otherness, linked to citizenship via tension and exclusion, is different from an emphasis on otherness linked to citizenship via ideas of accommodation or celebration of difference. The former can be understood as engagement which is defined through a struggle about what it means to be recognised as a "citizen" or to live within a "community", unlike the latter which is based upon the idea of a search for recognition and status within a pre-existing or an alternative more inclusive community. By introducing otherness and exclusion, this former idea of struggle challenges the necessary starting point of a bounded inclusive political community and the idea of a citizen who can be fully included in that community (as an individual who is separate from that community in the first place).

Migrant women's political engagement as discussed above indicates how their bodies are linked in various ways across society (to here, there, home culture, host culture, past, present and future) and to many other subjects (lovers, friends, neighbours, wider family, parents, grandparents); it is in this manner that it emphasises the broader idea of process as a starting point for the possibility of political identity and belonging. The navigation and coping strategies migrant women employ are linked in some respects to the gaps within the legal systems within which they are positioned - for example, the gaps which appear between border controls (which emphasise the need for formal citizenship or leave to remain) and legislation providing rights to people through family ties, as local residents or as asylum seekers. ${ }^{\text {ii }}$ These navigation and coping strategies are also linked to the ambiguities which emerge from how particular bodies are bonded across society: institutionally, emotionally, socially and economically. Such coping and navigation strategies are not, as such, specific to women's bodies precisely because of these wider bonds. Therefore, looking at women's bodies as a site for connections across society is fruitful because it simultaneously diverts 
attention away from these bodies towards the bonds which implicate all types of bodies (albeit with huge variants) at the site of "community" via family, friendship and collegiality. Such a focus foregrounds ideas of "being-together" and "being-with" (Nancy 2000) as the basis of community through these processes (the creation, maintenance and defence of family, friendship, collegiality); and highlights how bodies do not operate across pre-existing layers of "inclusion" and "exclusion", "local", "host", "national", "religious", "state", but rather they become stabilised through these ideas which also shift and change.

In her work, Shandy (2008, p.821) considers the image of children (the eventual Irishborn) "travelling without a passport by migrating in utero", bypassing borders as "they enter below the radar of the state". This image drives home the idea, I argue, of an intertwined subject which is very useful for thinking about a transitive form of being in the world which is not exceptional but rather is part of the possibility of being a citizen. The potential of focusing on reproduction, as such is that we can consider "how it presents a way of being-inthe-world with...interesting characteristics" rather than simply a process of producing a baby (Young 2005, p.10). This image can be used not only to reflect upon how some migrant women are pregnant upon arrival in a country; but more significantly on the constant possibility of a child in these lives and in the lives of those connected to them (fathers, lovers, friends, colleagues, neighbors) as that which is integral to membership in a given political community. The image of the fetus travelling in the womb emphasises the limits of understandings of individuals with sovereign autonomous rights who can be included coherently. It permits us, I argue, instead to consider how subjects are interconnected simultaneously to family, the past, the present, otherness, identity, places of birth and places of residence as the basis of political community; and therefore presents another starting point for citizenship: "at once both self and other, self and society, self and history, the historical and historicised self" (Jabri 2009 p.226).

The image of the child travelling in utero presents the idea of a contingent adaptable and fluid political subject which is more than a woman insofar as it is made also up of a child, yet less than a woman and a child as separate bounded subjects. This is a relationship in which existing and future relationships with fathers, friends, lovers, husbands and wider family members are implicated - further emphasising the contingent, adaptable and fluid nature of the marginalised subject which sits at the centre of discussions about birthright citizenship and questions of belonging. The result is a mother-child (born unborn) subject which, through their links to the future and to the past (generation) simultaneously, as well as their links both to/across Africa, Nigeria, Yoruba and Ireland, are thus ambiguously 
"included in" and "excluded from" the Irish political community simultaneously. It is difficult from this perspective any more to distinguish between these various relationships to overcome the exclusionary elements (associated with otherness) as they are constantly shifting and changing.

\section{Maternal Time: The Fragmented Time-Space of Being Political}

What the preceding discussion highlights is how a focus on reproduction undermines the dominant view - that the self and the other can be separated - within everyday life because "pregnancy is... an identity that splits, turns in on itself and changes without becoming other" (Kristeva 1986a, p.297). Battersby (1998, p.173) suggests that taking the body that births as the norm interrupts our models of identity because it emphasises the process through which identities emerge through the play of bodily relationships where "repetition ...brings into existence (births) an order of events that was already potentially there in the past". One of the ways in which we can understand this, I argue, is by turning to the question of how reproduction represents an alternative temporal dimension to linear (historical) national time which no longer simply acts to distinguish the self from an Other but links together the self and other through repetition and cycle, as discussed by Julia Kristeva in her work.

Kristeva notes (1986b, p.153) that national time is the linear time of progression, of speech and communication: "it provides the reference point, and, consequently, all possibilities of measurement, by distinguishing between a before, a now and an after". An example of how national time works in a linear manner can be seen in how the "citizen" is normally distinguished from the "migrant" (the latter as a future citizen only) because the citizen can link its existence in the present to previous citizen ancestors in the past, thus maintaining the necessary continuity for national affiliation which the migrant lacks. Such an ideal of linear national time has also been used to point to the arbitrary and violent nature of contemporary citizenship, in particular in settler societies (such as Canada, Australia or the USA) by revealing acts of disposition, subjugation and genocide of indigenous populations in the past. Linear historical national time has come to thus dominate discussions about citizenship.

Reproduction however introduces maternal time, Kristeva (1981, p.71) argues, which is linked both to cyclical time (repetition) given its association with menstruation and pregnancy, as well as monumental time (eternity) given its association with reproduction and the genetic chain. Here, time does not conclude but repeats itself constantly and interminably. 
It based on an inability to distinguish in the last instance between the present, future and past; as the future and past are ever-present. What is not immediately available is the ability to base the idea of "I" in a particular moment in time (the present) which can be distinguished from a similar moment, and therefore an "Other" in the future or the past. Past, present and future no longer follow on from one and other and separate the nation into different groups depending on moment of arrival, but the future is ever present (eternal) and/or runs into the past, which in turn runs into the present (cyclical). What becomes much more difficult here therefore is the ability to distinguish between a citizen - as a present or original member of the political community- and a migrant - as only a future possible member.

Julia Kristeva's work, I suggest, urges us to embrace how uncertainty, and ambiguity associated with strangeness, or otherness need not only be understood as a source of hopelessness or as something which must be overcome, but instead can be a positive force which presents opportunities "to reconsider the "foreignness" inherent in each of us" as key to our potential to form, maintain and recreate community $(1991$, p.4). We are left with the overlapping spatio-temporal subjectivity of the "migrant mother" and their child as a part of the political possibility of everyday life. Being-with others becomes part of the potential of political subjectivity because the potential of a child is linked to being-with a mother, and the potential of a mother is linked to being-with fathers, lovers, grandparents, neighbours, coworkers, fellow activists and so on. Doing so it undermines the rigid temporal lines which are so often drawn in relation to citizenship between relationships with parents (communities of descent) in contrast to relationships with wider family and friends (immediate relationships).

The political aspect of these overlapping relationships and how they exceed ideas of inclusion was highlighted on the $10^{\text {th }}$ anniversary of the 2004 Irish Referendum in June 2014 when protestors - predominately migrant mothers and their children - attended a rally in front of the Irish Parliament holding the slogan "Who Lives Here Belongs Here" (Irish Times 2014). By linking belonging to "living" and thus the everyday, rather than to a particular status, this slogan emphasised the idea of tying citizenship to the social fact of membership which cuts across social, legal, economic ties. Belonging is not immediately associated with "inclusion" here by being linked to a particular type of legal status such as citizenship by birth or naturalised citizenship; rather belonging is linked to participation which is often messy and results in contradictory, inconsistent inclusive-exclusive experiences, through the concept of "living". In other words, such public actions highlight the idea of a struggle over what it means to be recognised as "a citizen". 
Questioning the association of reproduction with "mere" repetition, Gedalof (2009) has demonstrated how change rather than just continuity is a key function of reproduction when childbirth and motherhood are situated within the broader work of heritage, culture and structures of belonging. This highlights the difficulty of pinning anything down as "inclusionary" or "exclusionary" in this sphere, as reproduction is "not simply about repeating fixed cultural traditions, but rather about actively negotiating difference" (ibid: 87). It is this active negotiation in the Irish example of the citizen-subject space in the appeal to the concept of "living" (which includes its messiness and exclusions) rather than appealing to a particular status, which subverts idea(1)s of citizenship as "inclusion" per se and why it is a useful example.

In her work Baraitser (2012a, p.236) argues in favour of thinking with multiple modalities of maternal time which are irreducible to and distinct from either cyclical or monumental time in order to recognize the potential of "maternal time" as force; that is, she considers how material time can be linked to the creation of forms, invention, the "continual elaboration of the absolutely new", rather than always as a (non)place without cleavage or escape. However, as I have noted above, Gedalof (2009: p.96) also highlights the importance of the "possibility of repetition that undoes" by bringing together the new and the familiar (the uncanny), which I argue emphasises the need to continue to theorize maternal time through cyclical and monumental time rather than beyond it if we are to do justice to the potential of the maternal as force in its ability to create newness. I'm suggesting then that we hold on to the importance of the "insistent and present tense of maternity" in eternal and cyclical time, at the same time as we explore/consider how this can be and is "recast as a kind of futurity...a break with the past that opens onto something new" (Baraitser 2012b, p.119). The "something new" I'm exploring is the way the persistent eternal and repetitive cyclical are recited and replayed in ways which exceed ideas of "inclusion" and "exclusion" by intertwining them and interrupting foundations upon which they are or can be anchored. This idea of newness in the eternal and the cyclical, rather than beyond this is in keeping I feel with Baraiter's own observation that her work with ideas like maternal time involve "a particular tension between movement and viscosity, endurance and interruption" forcing her into the task of "how to think 'newness' as a condition of 'stuckness"” (Baraitser 2012b, p.119)

The notion of maternal time in its cyclical and eternal nature, I argue, helps us to consider how reproduction introduces a different spatio-temporal understanding of what identity and belonging, and thus politics, can be. Working with the notion of maternal time 
helps us to think about how pregnancy potentially disorientates and displaces what we think we know about subjectivity. "Woman" can be reconceptualised as presence in subversive form which challenges the existing basis for "the synchronicity of the imagined community" (Bhabha 1994, p.158). A child is not simply the Other which woman produces but is part of the self which is simultaneously separate from the self across past, present and future. Instead of certain types of normalised bodies (the citizen) which can be contrasted with bodies temporally and spatially out of sync (the partial citizen), it allows us to think in terms of bodies existing as multiple cyclical and eternal variations of connections (bonds across society); connections which are then grounded in particularities, often depending on how relationships play out: whether people get married, whether they take on a job, or whether their claim for asylum is recognised etc. In doing so, it helps us rethink the relationship between bodies and legal codes. Rather than thinking about certain bodies having unusual connections (e.g. to home and away or to citizenship and migration) and transcending legal codes; it allows us to think about how legal codes themselves ground - as "citizen" or as "partial citizen" (migrant), as "included" or as "excluded", as "old citizen" or as "new citizen" - otherwise multiple possible forms of spatio-temporal bodily interconnections. In this manner, political possibility is no longer based predominantly (as a necessary starting point) on linear progressive time and absolute space where fluidity is an exception, but being political and citizenship can be understood as based in fluidity - in fragmented and inconsistent time(s).

\section{Conclusion}

The emphasis in this paper on public moments of migrant mother engagement builds on the links which have been drawn between a "maternal ethics" and "making things public" in Lisa Baraitser's work $(2009,2012)$ which divorces "mothering" from biological association and (among other things) emphasises how mothering makes public the ways in which we are collectively and affectively tied to one another. This paper builds on this by exploring specifically how mothering in/as public implicates multiple subjectivities - fathers, grandparents, neighbours, friends, colleagues, fellow activists, carers etc. In other words, it builds on already recognised understandings of the subversive nature of mothering and explores how mothering not only makes possible political identity but also reconfigures 'politics' by implicating many people across society. It argues that this challenges how we have come to 'know' citizenship by linking it to commonality and otherness simultaneously. 
The ethical potential for such a starting point for thinking about citizenship across inclusion and exclusion here lies in the way it enables us to see how migrants are positioning themselves along with other groups in society (such as those who are suffering welfare benefit cuts) as another type of citizen, and thus as key members. It enables us to start to consider how they are positioning themselves vis-a-vis the question of marginalization, as other groups do who struggle to be heard as political members of society. It pushes us to consider further how they can do this rather than needing to position themselves always as non-citizens which defines them in terms of a lack - understood as being at a lesser stage of inclusion (economic, social, political rights) in political community, which requires recognition from other citizen groups regarding their key contributions to the formation of political community. From this starting point a space is opened up precisely for different experiences of political engagement to be invoked as 'citizenship' here in way that does not rank them hierarchically as more or less inclusive but allows for recognition of the constitutive nature of inclusion (repetition) and exclusion (interruption) in citizenship, given the shifting and sliding nature of such experiences and thus the constant possibilities of reconfiguring citizenship anew.

\section{Bibliography:}

AkiDwa (2013) Evaluation Report: Migrant Women's Health Service Project. 6: 1-26 http://www.akidwa.ie/publications/gender-based-violence/female-genital$\underline{\text { mutilation.html }}$

Andrijasevic R (2009) Sex on the Move: Gender, Subjectivity and Differential Inclusion. Subjectivity 29: 389-406

Balibar É (2000) What we Owe to the Sans-Papiers. In: L Guenther and C Heesters (eds.) Social Insecurity. Toronto: Anansi, 42-43

Balibar É (2012) The "Impossible" Community of the Citizens: Past and Present Problems. Society and Space 30(3): 437-49

Baraitser L (2009) Mothers who Make Things Public. Feminist Review 93: 8-26

Baraitser L (2012a) Maternal Publics: Time, Relationality and the Public Sphere. In A. Gulerce (ed.) Re(con)figuring Psychoanalysis (Basingstoke: Palgrave Macmillan): 221-240

Baraitser L (2012b) Communality across Time. Studies in Gender and Sexuality 13: 117-122 
Baraitser L and Tyler I (2013) Private View, Public Birth: Making Feminist Sense of the New Visual Culture of Childbirth. Studies in the Maternal 5(2): online 1-27

Battersby C (1998) The Phenomenal Woman: Feminist Metaphysics and the Patterns of Identity. London: Routledge

Bauböck R (2011) Temporary Migrants, Partial Citizenship and Hypermigration. Critical Review of International Social and Political Philosophy 14(5): 661-693

Bhabha H (1994) The Location of Culture. London: Routledge

Bhabha J (2009) 'The Mere Fortuity of Birth'? Children, Mothers, Borders and the Meaning of Citizenship. In: S Benhabib and J Resnik (eds.) Migrations and Mobilities: Citizenship, Borders and Gender. NY: NY University Press, 187-227

Bosniak L (2006) The Citizen and the Alien. Princeton: Princeton University Press

Clarke J., Coll K., Daginino E., and Neveu, C. (2014) Disputing Citizenship. Policy Press

Closs Stephens A (2010) Citizenship without Community: Time, Design and the City, Citizenship Studies 14(1) 31-46

Closs Stephens A and Squire V (2012) Politics through a Web: Citizenship and Community Unbound. Society and Space 30(3): 551-567

Dauvergne C (2009) Globalizing Fragmentation: New Pressures on Women Caught in the Immigration Law-Citizenship Law Dichotomy. In J. Benhabib and J. Resnik (eds.) Migrations and Mobilities. London: New York University Press

Erel, U (2009) Migrant Women Transforming Citizenship: Life Stories from Britain and Germany. London: Ashgate

Erel U (2013) Kurdish Migrant Mothers in London Enacting Citizenship. Citizenship Studies 17(8): 970-984

Erel, U, Haraitaworn, J., Gutiérrez-Rodrígiez. E. and Klesse, C. (2010) On the Depoliticisation of Intersectionality Talk. In K. Adi and M Esperanza (eds) Out of Place: Interrogating Silences in Queerness/Raciality. NY: Raw Nerve Books: 265292

Garner S (2007) Babies, Bodies and Entitlement: Gendered Aspects of Access to Citizenship in the Republic of Ireland. Parliamentary Affairs 60(3): 437-452

Hanafin M (2004) Why we have to close citizenship loophole. The Irish Independent 19 May

Honohan I (2007) Bounded Citizenship and the Meaning of Citizenship Laws. In L Cardinal and N Brown (eds.) Managing Diversity: Practices of Citizenship in Australia, Canada and Ireland. Ottawa: University of Ottawa Press, 63-94 
Howard M (2009) The Politics of Citizenship in Europe. Cambridge: Cambridge University Press

Irish Constitution, (2012) Dublin: Stationary Office

Irish Times (2014) Rally Challenges Citizenship Restrictions. The Irish Times, 12 June

Isin E (2002) Being Political: Genealogies of Citizenship. Minneapolis: University of Minnesota Press

Isin, E (2009) Citizenship in Flux: The Figure of the Activist Citizen. Subjectivity 29: 367388

Isin E and Neilson G, (eds) (2008) Acts of Citizenship. London: Zed Books

Jabri V (2009) Julia Kristeva In J Edkins and N Vaughan-Williams (eds.) Critical Theorists and International Relations (eds.) London: Routledge, 221-34

Kristeva J (1981) Women's Time. Signs. trans. A. Jardine and H. Blake, 7(1): 13-35

Kristeva J (1986a) A New Type of Intellectual: The Dissident. In Toril Moi (ed.) The Kristeva Reader. New York: Columbia University Press, 292-300

Kristeva J (1986b) About Chinese Women In: Toril Moi (ed.) The Kristeva Reader. New York: Columbia University Press, 138-59

Kristeva J (1991) Strangers to Ourselves. trans. Leon S. Roudiez. New York: Columbia University Press

Lentin R (2004) Strangers and Strollers: Feminist Notes on Researching Migrant M/others Women's Studies International Forum 27(4): 301-14

Lister R (2007) Inclusive Citizenship, Realising the Potential. Citizenship Studies 11(1): 4961

Luibhéid E (2004) Childbearing against the State? Asylum Seeker Women in the Irish Republic. Women's Studies International Forum 27(4): 335-49

Luibhéid E (2013) Pregnant on Arrival: Making the Illegal Immigrant. Minneapolis: University of Minnesota Press

McNevin A (2011) Contesting Citizenship: Irregular Migration and New Frontiers of the Political. New York: Columbia University Press

Mezzadra S (2011) The Gaze of Autonomy In V. Squire (ed.) The Contested Politics of Mobility: Borderzones and Irregularity. London: Routledge, 121-142

Mezzadra S and Neilson B (2012) Between Inclusion and Exclusion: On the Topology of Global Space and Borders, Theory Culture and Society 29: 58-75 
Mezzadra S and Rahola F (2006) The Postcolonial Condition: A few Notes on the Quality of Historical Time in the Global Present. Postcolonial Text 2(1)

Mullally S (2005) Debating Reproductive Rights in Ireland. Human Rights Quarterly 27(1): $78-104$

Mullally S (2009) Migrant Women Destabilizing Borders: Citizenship Debates in Ireland. In: E Grabham, D Cooper, J Krishnadas, and D Herman (eds.) Intersectionality and Beyond. Abingdon: Routledge, 251-70

Nancy JL (2000) Being Singular Plural. California: Stanford University Press

Ngai M (2007) Birthright Citizenship and the Alien Citizen. Fordham Law Review 75(5): $2521-2530$

Ní Mhurchú, A. (2014a) Citizenship Beyond State Sovereignty. In E. Isin and P Nyers (eds.) Routledge Handbook of Global Citizenship Studies. Abingdon: Routledge, 119-127

Ní Mhurchú, A. (2014b) Ambiguous Citizenship in an Age of Global Migration. Edinburgh: Edinburgh University Press

Nyers P (2011) Forms of Irregular Citizenship. In: V. Squire (ed.) The Contested Politics of Mobility: Borderzones and Irregularity. London: Routledge, 184-198

Oaks, L., (1998) Irishness, Eurocitizens, and Reproductive Rights. In: S. Franklin and H. Ragone (eds) Reproducing Reproduction: Kinship, Power, and Technological Innovation. Philadelphia: University of Pennsylvania Press, 132-55

Ong, A., (1999) Flexible Citizenship: The Cultural Logics of Transnationality. Durham: Duke University

Oyewumi O (2010) Introduction: Gendering. In: O Oyewumi (ed.) Gender Epistemologies in Africa. Hampshire: Palgrave Macmillan, 1-9

Raissiguier C (2010) Reinventing the Republic: Gender, Migration, and Citizenship in France. Stanford: Stanford University Press

Reynolds T (2005) Caribbean Mothers: Identity and Experience in the UK (London: Tufnell Press)

Rigo E (2011) Citizens Despite Borders: Challenges to the Territorial Order of Europe. In V Squire (ed.) The Contested Politics of Mobility: Borderzones and Irregularity. London: Routledge: 199-215

Rosaldo R (1994) Cultural Citizenship in San Jose, California. PoLAR 17 (2): 57-64

Sarat A (2013) Who Belongs? Immigration, Citizenship and the Constitution of Legality, Special Issue, Studies in Law, Politics and Society 60: 1-111 
Sawyer C and Blitz BK (2011) Statelessness in the European Union: Displaced, Undocumented, Unwanted. Cambridge: Cambridge University Press

Seely JC, Diouf ED, Malischewski CA, Viakath M, and Young-Burns K (2013) Second-class Citizens? Gender in African Citizenship Law. Citizenship Studies 17(3): 429-446

Shachar A (2009) The Birthright Lottery. London: Harvard University Press

Shandy DJ (2008) Irish Babies, African Mothers: Rites of Passage and Rights in Citizenship in Post-Millennia Ireland. Anthropological Quarterly 81(4): 803-31

Smith A (2008) The Irish Citizenship Referendum (2004): Motherhood and Belonging. In: D Reed-Danahay and CB Brettell (eds.) Citizenship, Political Engagement, and Belonging. NJ: Rutgers University Press, 60-77

Turner J (forthcoming 2016) Engendering the Political: Citizenship from Marginal Spaces. Special Issue on Engendering Citizenship, Citizenship Studies

Vertovec, S. (2007) Super-Diversity and Its Implications. Ethnic and Racial Studies, 30(6): 1024-1054

Walker RBJ (2010) After the Globe, Before the World. Abingdon: Routledge

Weber C (2011) I am an American: Filming the Fear of Difference. Bristol: Intellect

Young IM (2005) On Female Body Experience. New York: Oxford University Press

Yuval-Davis N and Anthias F (eds) (1989) Women-Nation-State. London: Macmillan

\footnotetext{
${ }^{\mathrm{i}}$ See, for example, some other approaches and discussions within the intersectionality literature which specifically critique the idea of "axis" of differentiation. These point instead to intermeshing forms of oppression which are constitutive of subjects, thereby undermining the notion of the unitary subject more systematically (e.g. Erel et al 2010).

${ }^{\text {ii }}$ In most European countries, for example, all residents (of 6 months) are entitled to vote regardless of their status in municipal elections. In many countries asylum seekers are entitled to work after a period of time.
} 